\title{
AN OVERVIEW OF BIRD MIGRATION STUDIES IN EGYPT
}

\author{
Wed Abdel Latif Ibrahim
}

\begin{abstract}
Ibrahim W.A.L. 2011. An overview of bird migration studies in Egypt. Ring 33, 1-2: 55-75.

This is an overview of ornithological studies carried out in Egypt since the beginning of $\mathrm{XX}^{\text {th }}$ century till the present time made on the basis of several more or less general publications. Geographical location and climate descriptions give the background information about the area. The literature overview stresses especially problems connected with the migration of passerines, but wider avifaunistic background is discussed as well. Special attention is paid to the passerines' strategy of migration through the Mediterranean Sea and Sahara Desert, its direction and timing, as well as to the factors affecting passerines migration and bird ringing in Egypt. In conclusion, it is stressed that the studies on bird migration were done sporadically, from time to time and from one place to another, and there is a dramatic lack of permanent ringing / bird migration study field stations, despite the fact that some suitable and promising localities have been found, in which the studies have been carried out since 2001 by the SE European Bird Migration Network in cooperation with some protected areas managements.
\end{abstract}

W.A.L. Ibrahim, Nature Conservation Sector, Egyptian Environmental Affairs Agency, 30 Misr Helwan El-Zyrae Road, Maadi, Cairo, Egypt, E-mail: wed_abdou@yahoo.com Publication appointed to the SE European Bird Migration Network papers

Key words: bird migration, Egypt, studies, overview

\section{INTRODUCTION}

The Afro-tropical region receives migrant birds from the northern hemisphere. The number of Palearctic birds arriving in African sub-Sahara is estimated at 3750 million individuals, about one million of which are waterbirds (Moreau 1972). The area of only 20 million $\mathrm{km}^{2}$ is capable of receiving the migrants, out of 29 million $\mathrm{km}^{2}$ of African territory. The rest is occupied by the inhospitable Sahara (BirdLife 2005).

One of the main flyways for migration from Palearctic to Africa is the River Jordan to the Nile Valley, which is considered as the most significant corridor for bird migration in the world, and is the main eastern corridor between Europe/Asia and Africa used by millions of birds to pass through a series of migratory bottleneck sites 
during migration seasons. From this corridor, birds enter Egypt and then fly through Sudan, Uganda, Kenya, Tanzania and southern Africa (Malawi, Zimbabwe and South Africa). This route takes birds from central Europe, the Middle East and Central Asia (BirdLife 2005).

Avifauna is an important component of the Egyptian biological resources; indeed, it is the most diverse and prominent of all the country's non-aquatic vertebrate fauna (Baha El Din 1999). More than 470 bird species were recorded in Egypt. The majority are non-breeding seasonal visitors (Fishpool and Evans 2001). In Egypt, about 150 species are breeding residents, found all year round (Baha El Din 1999). Egypt has an international importance for birds with globally significant populations of breeding, wintering and migrating birds, including some 19 globally threatened species (IUCN 2000) and 34 sites declared as Important Bird Areas (Baha El Din 1999). In the present paper it is important to shed some light on the general landscape and habitat characteristics of Egypt, which would be essential in the interpretation and evaluation of the studies carried out within the area.

\section{GEOGRAPHICAL LOCATION}

The following text is cited after Wikipedia (2011). Egypt is located in the northern part of Africa, however, it includes the Sinai Peninsula, which is considered as a part of south-western Asia. The country has shorelines on the Mediterranean Sea and the Red Sea. It borders Libya to the west, Sudan to the south, and the Gaza Strip to the east. Egypt covers $1001449 \mathrm{~km}^{2}$ of land. Its longest distance from north to south is 1024 kilometres, and from east to west - 1240 kilometres. Egypt's natural boundaries cover more than $2900 \mathrm{~km}$ of coastline along the Mediterranean Sea, the Gulf of Suez, the Gulf of Aqaba and the Red Sea (Wikipedia 2010).

Egypt is divided into twenty-six governorates, which include four city governorates: Alexandria (Al Iskandariyah), Cairo (Al Qahirah), Port Said (Bur Said) and Suez. Also included are the nine governorates of Lower Egypt in the Nile Delta region, the eight governorates of Upper Egypt along the Nile south from Cairo to Aswan, and the five frontier governorates covering Sinai and the deserts that are located west and east of the Nile.

Egypt is predominantly desert land. An area of only $35000 \mathrm{~km}^{2}-3.5 \%$ of the total land area - is cultivated and permanently settled. Most of the country is within the wide band of desert that stretches from Africa's Atlantic Coast across the continent and into south-western Asia.

According to Egypt's geological history four major physical regions can be distinguished (David 1997, Hopkins and Westergaard 1998): (1) the Nile Valley and Delta, (2) the Western Desert, also known as the Libyan Desert, (3) the Eastern Desert, also known as the Arabian Desert, (4) the Sinai Peninsula.

\section{Nile Valley and Delta}

Despite covering only about $5.5 \%$ of the total area of Egypt, the Nile Valley and Delta are the most important regions, being the country's only cultivable regions and 
supporting about $99 \%$ of the population. The Nile Valley and Delta, the most extensive oasis on Earth, was created by the world's longest river and its seemingly inexhaustible resources. Without the topographic channel that permits the Nile to flow across the Sahara, Egypt would be entirely desert. The Nile traverses about $1600 \mathrm{~km}$ through Egypt and flows northward from the Egyptian-Sudanese border to the Mediterranean Sea. The Nile is a combination of three long rivers, which sources are in central Africa: the White Nile, the Blue Nile and the Atbarah.

The Nile enters Egypt a few kilometres north of Wadi Halfa, a Sudanese town that was completely rebuilt on high ground when its original site was submerged in the reservoir created by the Aswan High Dam. As a result of the dam's construction, the Nile actually begins its flow into Egypt as Lake Nasser, which extends south from the dam $320 \mathrm{~km}$ to the border and additional $158 \mathrm{~km}$ into Sudan.

Lake Nasser's waters fill the area through Lower Nubia (Upper Egypt and northern Sudan) within the narrow gorge between the cliffs of sandstone and granite created by the flow of the river over many centuries. Below Aswan the cultivated floodplain strip widens to as much as $20 \mathrm{~km}$. North of Isna (160 km north of Aswan), the plateau on both sides of the valley rises as high as $550 \mathrm{~m}$ a.s.l.; at Qina (about $90 \mathrm{~km}$ north of Isna) the $300 \mathrm{~m}$ high limestone cliffs force the Nile to change course to the south-west for about $60 \mathrm{~km}$ before turning north-west for about $160 \mathrm{~km}$ to Asyut. Northward from Asyut, the escarpments on both sides diminish, and the valley widens to a maximum of $22 \mathrm{~km}$. The Nile reaches the Delta at Cairo.

At Cairo, the Nile spreads out over what was once a broad estuary that had been filled by silt deposits to form a fertile, fan-shape delta about $250 \mathrm{~km}$ wide at the seaward base and about $160 \mathrm{~km}$ from north to south. The Nile Delta extends over approximately $22000 \mathrm{~km}^{2}$. According to historical accounts from the first century A.D., seven branches of the Nile once ran through the Delta. According to later accounts, the Nile had only six branches by around the $12^{\text {th }}$ century. Since then, nature and man have closed all but two main outlets: the east branch - Damietta (also known as Dumyat, $240 \mathrm{~km}$ long) and the west branch - Rosetta (235 km long). Both outlets are named after the ports located at their mouths. A network of drainage and irrigation canals supplements these remaining outlets. In the north near the coast, the Delta embraces a series of salt marsh and lakes. The most notable among them are Edku, Burullus, and Manzala.

\section{Western Desert}

The Western Desert covers about $700000 \mathrm{~km}^{2}$ and accounts for about two-thirds of Egypt's land area. This immense desert to the west of the Nile spans the area from the Mediterranean Sea south to the Sudanese border. The desert's Jilf al Kabir Plateau has an altitude of about $1000 \mathrm{~m}$, and is an exception to the uninterrupted territory of basement rocks covered by layers of horizontally bedded sediments forming a massive plain or low plateau. The Great Sand Sea lies within the desert's plain and extends from the Siwa Oasis to Jilf al Kabir. Escarpments (ridges) and deep depressions (basins) exist in several parts of the Western Desert and no rivers or streams drain into or out of the area. 
The government has considered the Western Desert a frontier region and has divided it into two governorates at about the twenty-eighth parallel: Matruh to the north and New Valley (Al Wadi al Jadid) to the south. There are seven important depressions in the Western Desert and all are considered oases except the largest, Qattara, the water of which is salty. The Qattara Depression is approximately $15000 \mathrm{~km}^{2}$ and is largely below sea level (its lowest point is $133 \mathrm{~m}$ b.s.l.). Badlands, salt marshes, and salt lakes cover the sparsely inhabited Qattara Depression.

Limited agricultural production, the presence of some natural resources, and permanent settlements are found in the other six depressions, all of which have fresh water provided by the Nile or by local groundwater. The Siwa Oasis, close to the Libyan border and west of Qattara, is isolated from the rest of Egypt but has sustained life since ancient times.

The other major oases form a topographic chain of basins extending from the Faiyum Oasis (sometimes called the Fayyum Depression), which lies $60 \mathrm{~km}$ south-west of Cairo, south to the Bahariya, Farafirah, and Dakhilah oases before reaching the country's largest oasis, Kharijah. A brackish lake, Birket Qarun, at the northern reaches of Al Fayyum Oasis, drained into the Nile in ancient times. For centuries sweet water of artesian wells in the Fayyum Oasis have permitted extensive cultivation in an irrigated area that extends over $1800 \mathrm{~km}^{2}$.

\section{Eastern Desert}

The topographic features of the region east of the Nile are very different from those of the Western Desert. The relatively mountainous Eastern Desert rises abruptly from the Nile and extends over an area of approximately $220000 \mathrm{~km}^{2}$. The upwardsloping plateau of sand gives way within $100 \mathrm{~km}$ to arid, defoliated, rocky hills running north and south between the Sudan border and the Delta. The hills reach elevations of more than $1900 \mathrm{~m}$. The region's most prominent feature is the easterly chain of rugged mountains, the Red Sea Hills, which extends from the Nile Valley eastward to the Gulf of Suez and the Red Sea. This elevated region has a natural drainage pattern that rarely functions because of insufficient rainfall. It also has a complex of irregular, sharply cut valleys (wadi) that extend westward toward the Nile.

The Eastern Desert is generally isolated from the rest of the country. There is no oasis cultivation in the region because of the difficulty in sustaining any form of agriculture. Except for a few villages on the Red Sea coast, there are no permanent settlements. The importance of the Eastern Desert lies in its natural resources, especially oil. A single governorate, the capital of which is at Al Ghardaqah, administers the entire region.

\section{Sinai Peninsula}

This triangular area covers about $61100 \mathrm{~km}^{2}$. Similar to the desert, the peninsula contains mountains in its southern sector that are a geological extension of the Red Sea Hills, the low range along the Red Sea coast that includes Mount Catherine (Jabal Katrinah), the country's highest point of $2642 \mathrm{~m}$. The Red Sea may have been 
named after these mountains, which are red. The southern side of the peninsula has a sharp escarpment that subsides after a narrow coastal shelf that slopes into the Red Sea and the Gulf of Aqaba. The elevation of Sinai's southern rim is about $1000 \mathrm{~m}$. Moving northward, the elevation of this limestone plateau decreases. The northern third of Sinai is a flat, sandy coastal plain, which extends from the Suez Canal into the Gaza Strip.

\section{CLIMATE}

The following text is cited after Encyclopaedia Britannica (2011). Egypt lies within the North African desert belt; its general climatic characteristics, therefore, are low annual precipitation and a considerable seasonal and diurnal (daily) temperature range, with sunshine occurring throughout the year. In the desert, cyclones stir up sandstorms or dust storms, called khamsins (as they are said to come 50 days per year), which occur most frequently from March to June; these are caused by tropical air from the south that moves northward as a result of the extension north eastward of the low-pressure system of the Sudan. A khamsin is accompanied by a sharp increase in temperature of 8 to $11^{\circ} \mathrm{C}$, a drop in relative humidity (often to $10 \%$ ) and thick dust; winds can reach gale force.

The climate is basically bi-seasonal, with winter lasting from November to March and summer from May to September, with short transitional periods intervening. The winters are cool and mild while the summers are hot. Mean January minimum and maximum temperatures show a variation between 9 to $18^{\circ} \mathrm{C}$ in Alexandria and 9 to $23^{\circ} \mathrm{C}$ at Aswan. The summer months are hot throughout the country's inland, with mean midday high temperatures in June ranging from $33^{\circ} \mathrm{C}$ at Cairo to $41^{\circ} \mathrm{C}$ at Aswan. Egypt enjoys a very sunny climate, with some $12 \mathrm{~h}$ of sunshine per day in the summer months and between 8 and $10 \mathrm{~h}$ per day in winter. Extremes of temperature can occur and prolonged winter cold spells or summer heat waves are common.

Humidity diminishes noticeably from north to south and on the desert fringes. Along the Mediterranean coast the humidity is high throughout the year, but it is highest in summer. When high humidity levels coincide with high temperatures, oppressive conditions result.

Precipitation in Egypt occurs largely in the winter months; it is meagre on average but highly variable. The amount diminishes sharply southward; the annual average at Alexandria is about $175 \mathrm{~mm}$, Cairo has about $25 \mathrm{~mm}$, and Aswan receives virtually nothing - only about $2.5 \mathrm{~mm}$. The Red Sea coastal plain and the Western Desert are almost without precipitation. The Sinai Peninsula receives somewhat more precipitation: the northern sector has an annual average of about $125 \mathrm{~mm}$.

\section{LITERATURE REVIEW}

Although Egypt has a long history of ornithological research, relatively little information is known on the non-Nilotic parts of the country. In a 1969 paper R. Moreau, stated (notwithstanding the imposing two volumes of Nicoll and Meinertzhagen 
1930) that Egypt south of Cairo and on both sides of the Nile Valley remained one of the worst-documented parts of Africa. The past years have seen a surge of interest in Egyptian ornithology and substantial areas of the country, hitherto unknown, have been surveyed. The book "The birds of Egypt" (Goodman et al. 1989) aimed to synthesize the new information on the birds of Egypt and to some extent re-evaluate the material available to Nicoll and Meinertzhagen (1930).

After the death of M. Nicoll (the Assistant Director of the Zoological Gardens of Giza) in 1925, a partially composed manuscript that he had been writing on Egyptian birds was turned over to R. Meinertzhagen - a British officer and notorious birdenthusiast. This manuscript clearly formed an integral portion of Meinertzhagen's book published in 1930 (Nicoll and Meinertzhagen 1930). Much of the late XVIII ${ }^{\text {th }}$, $\mathrm{XIX}^{\text {th }}$, and early $\mathrm{XX}^{\text {th }}$ century literature and work on Egyptian ornithology was summarized by Meinertzhagen and the intent of this section is to briefly review work conducted in the Egypt since then.

\section{Background}

A. Koenig (a German naturalist and zoologist) published several substantial monographs on the birds of the country and the Nile, mostly in the "Journal für Ornithologie” between 1907 and 1936 (Koenig 1907a, b, c; 1917; 1919; 1920a, b, c; 1921; 1924; 1926a, b, c; 1928; 1932a, b, c). A. Al Hussaini gave an important figure in Egyptian ornithology. In the mid- to late 1930s he explored areas of the Western Desert and the Red Sea coast and published several papers on bird observations (Al Hussaini 1938a, b; 1938-1939; 1939). His work also included a book (in 1940) in Arabic on the birds of Egypt, which was revised in 1954 (Al Hussaini 1954). A. El Negumi surveyed remote desert areas, particularly the Eastern Desert, in the late 1940s and 1950s and made the bird collections which are housed in the Giza Zoological Museum (El Negumi 1949). In 1950 El Negumi, together with several colleagues, published a book that remains the standard work in Arabic on the birds of the country (El Negumi et al. 1950).

The British influence on the twentieth century Egyptian ornithology was significant. Until 1936 Egypt remained under British military occupation and numerous armed forces and civil personnel made important ornithological contributions. One individual at the forefront was R. Moreau, whose publications dealing with Egyptian ornithology span 41 years, from 1929 to 1970 (Moreau and Moreau 1937; Moreau 1961, 1969; Moreau and Dolp 1970; Moreau 1972). At least from June 1944 to February 1945 R. H. Greaves was compiling monthly bird observation notes, which were distributed by educational authorities to local naturalists. Between the late 1940s and the mid-1950s the British army occupied various positions along the Suez Canal. From 1949 to at least 1951 the cyclostyled "Bulletin of the Fayid Ornithological Club" was distributed to members, mostly British military personnel stationed along the Suez Canal. At least 16 issues were circulated. H. G. Brownlow edited numbers 1-12 and A. Critchley numbers 13-16. These bulletins contained information on ringing projects, important bird observations, and general bird notes. A ringing station was operated at Fayid and several detailed natural history studies on local breeding birds 
were made by this group of people (e.g. Simmons 1952, 1954a) as well as the observations of migrants (e.g. Simmons 1951, 1954b).

R. H. Greaves (1945) and E. G. M. Goodwin (1947a) realized the magnitude of raptor migration along the Suez Canal. In 1945 a leaflet was published in the "Bulletin of the Zoological Society of Egypt" illustrating the flight profile and markings of several raptors in order to, at least in part, spur interest in raptor counts (Greaves 1945). Meanwhile, E. G. M. Goodwin conducted one of the earliest radar studies on birds all over the world. He measured the altitude and speed of raptor passing at the Suez Canal (Goodwin 1947b). More thoroughly, D. Goodwin (1949) and K. E. L. Simmons (1951) subsequently performed raptor migration counts.

Starting in the mid-1950s, H. Hoogstraal and his colleagues from the United States, Naval Medical Research Unit Number Three (NAMRU3) in Cairo, commenced studies in Egypt on the relationships of ticks and their vertebrate hosts with the transmission of arboviruses. Birds were an important group in this research. Through netting, collecting and visiting wild bird markets a considerable amount of new information was obtained. Hoogstraal and others (Hoogstraal and Kaiser 1961, Hoogstraal et al. 1961, Hoogstraal et al. 1963, Hoogstraal et al. 1964) summarized some earlier NAMRU3 bird migration studies. The majority of NAMRU3 bird material was deposited in the Field Museum of Natural History, Chicago. It should be noted that for several decades Hoogstraal and other researchers studying Egyptian zoology obtained specimens from the commercial hunters and trappers of Abu Rauwash and Giza.

In 1957, an expedition from the Natural History Museum in Budapest visited Egypt and obtained a considerable amount of new information. L. Horváth (1959) published the general results of this expedition. Some of the material collected on this trip included the individuals of Ammomanes deserti borosi (Horváth 1958), the most recently named endemic bird from the country.

In three field seasons between 1962 and 1965 the Yale University Prehistoric Expedition to Nubia worked in the part of the Nile Valley now inundated by Lake Nasser. The field team consisted of several zoologists, including T. Lovejoy, Ch. Maser and Ch. Reed. The data and materials they gathered were particularly important because they represented the last information on the birds of this area before it was completely flooded by Lake Nasser (Reed 1966). The specimens obtained by this group are deposited in the Yale Peabody Museum of Natural History in New Haven.

From 1966 to 1973 the Palaearctic Migratory Bird Survey, under the direction of George E. Watson and in collaboration with NAMRU3 and Yale Arbovirus Research Unit, conducted a serological study of migratory birds and their ectoparasites in north-eastern Africa. The autumn field seasons of 1966 and 1968-1972 and spring seasons of 1967 and 1969-1973 were held in Egypt, primarily along the northern coast and in the Nile Delta. Information on some of the collected ornithological data was summarized and analysed by G. E. Watson (1971) and K. O. Horner (1977). Collected specimens were deposited in the National Museum of Natural History, Washington, DC.

In the early 1970s D. Lavee and U. Safriel of the Hebrew University in Jerusalem studied bird migration in the south Sinai mountains. Their main research site was the 
garden of the Saint Katherine Monastery during autumn. This work concentrated on the species passing through or wintering in the region and the importance of isolated oases as refuelling sites for migrants (Lavee and Safriel 1974). Voucher specimens were collected and deposited in the Zoological Museum of the Hebrew University of Jerusalem.

Perhaps no area of the country still remains as poorly known as the vast territory of the Western Desert, particularly the most remote and inaccessible areas. Between 20 October 1968 and 15 January 1969 a Belgian expedition surveyed the vertebrate life of the Gebel Uweinat and Gilf Kebir areas. The ornithological results were published by X. Misonne (1974) and to a great extent are the basis of our current knowledge of the birds occurring at these two sites. During spring seasons of 1976 and 1977 S. M. Goodman and P. L. Ames visited Siwa oases and Qattara Depression. They made summary of birds collections and field observations in this area. During their work 69 species were reported of which 45 species had specimen documentation; it was published by the Ornithological Society of the Middle East (OSME) in 1983 (Goodman and Ames 1983). A number of ornithologists visited the more accessible areas of the Western Desert and this information was summarized by Goodman et al. (1986). During four migratory seasons from 1980 to 1985, H. Biebach and his colleagues of the Max-Planck Institute fr Verhalternsphysiologie studied bird migration in Bahariya oases. This work was particularly useful in illustrating the species composition and behavioural strategies of birds crossing the Egyptian portion of Sahara (Biebach 1985, 1988, 1990, 1992, 1996; Biebach et al. 1986; Biebach et al. 1991; Biebach et al. 2000).

The foundation of the Egyptian Wildlife Services (EWS) in 1979 heralded a new era in zoological field studies and national conservation practices. EWS rangers regularly visited remote areas of the country and have added more information to our knowledge of local avifauna. Further, this agency has facilitated numerous ornithological field studies conducted by foreigners. Perhaps the most important development was the creation of the Ornithological Society of Egypt (OSE) in 1982. Some of the prime goals of the OSE were to promote ornithological studies in Egypt and national interest in educating local people about birds and conservation. The organ of the society, the Courser, provided an excellent medium for presenting this information.

In 1979, P. L. Meininger and W. C. Mullié launched "The birds of Egypt" project. In the following years, three other authors of the book "The birds of Egypt" (i.e. S.M. Goodman, S. M. Baha El Din and J. J. Hobbs) joined this working group. Requests for information on Egyptian birds were published in several European and North American ornithological journals and newsletters. By mid-May 1988 over 250 responses were received from various institutions and people sending unpublished information on the birds of the Egypt. This book was a collaborative effort by all the authors. Several points should however be mentioned about particular aspects of its production. The project widely used records of different bird species collected by organized bird watching tours to the country. The majority of these groups confined their trips to the Nile Delta and Valley. Two regular tours of particular note were the American Natural History Museum and the Swan Hellenic/Royal Society for the Pro- 
tection of Birds. The former group had visited the country almost every year since 1976 and records up to 1979 were summarized by L. L. Short and J. F. M. Horne (Short and Horne 1982). An important source of information on the migratory movements of birds passing through Egypt, particularly waterbirds, were different surveys that were systematically conducted along the north coast of Sinai. The periods of these surveys covered 13 August - 29 September 1973 and 15 August - 7 October 1978 (Paran and Paz unpubl.), 11-20 October 1979 (Petersen and Sørensen 1980), 7-30 September 1980 (Petersen and Sørensen 1981a), 16 August - 24 September 1981 (Petersen and Sørensen 1981b) and 2-24 September 1982 (Baha El Din and Salama 1984). During the winters of $1978 / 1979$ and $1979 / 1980$, the surveys of waterbirds on the Egyptian wetlands clearly documented the importance of these areas, particularly for Palearctic migrants (Meininger and Mullie 1982). In the spring of 1983 the group visited the Nile Delta lakes to document the local breeding birds (Meininger et al. 1986). "The birds of Egypt" presented geography, conservation, hunting and responses of birds to changing environment (Goodman et al. 1989).

In 1990, N. Varty, S. M. Baha El Din and W. Salama published an assessment of the importance of Lake Bardawil for birds and the likely impact of the north Sinai agriculture development project on the region's birds and their habitat. About 91 species of migrating birds were recorded in Lake Bardawil, particularly waterbirds and passerines (Varty et al. 1990).

In 1994, P. L. Meininger and G. A. M. Atta presented comprehensive ornithological studies on Egyptian wetlands. They assessed the importance of Egyptian wetlands for the birds and the impact of human activities on wetlands and birds population (Meininger and Atta 1994).

J. G. Frazier, S. S. Salas and M. A. Saleh presented their observations along the Egyptian Red Sea coast during spring 1982 (Frazier et al. 1984). M. C. Jennings, P. C. Heathcote, D. Parr and S. M. Baha El Din surveyed the islands in the Hurghada Archipelago during spring 1983 and autumn 1984 (Jennings et al. 1985). S. M. Goodman and R. W. Storer surveyed the islands in the southern Egyptian Red Sea (Goodman and Storer 1987). M. Rosenzweig presented some observations on the islands of Hurghada (Rosenzweig 1988). R. Hoath, D. Russel, R. and D. Khalil discussed their visit to some islands at the mouth of the Gulf of Suez (Hoath et al. 1997). A. Grieve and L. B. Millington produced a report on the northern Red Sea islands (Grieve and Millington 1999), representing the most comprehensive survey of the status of breeding seabirds in this area since Jenning's survey, with additional records from a visit to Wadi El Gemal Islands and Hamata Mangroves in September 2000.

S. M. Baha El Din (1999) assessed and identified the Important Birds Areas in Egypt according to the available information including new records.

In 2002, M. and S. Baha El Din and M. Shobrak presented the status of breeding seabirds in the Egyptian Red Sea; they assessed the status of 22 breeding species, out of which 9 are true seabirds (Baha El Din et al. 2003).

In 2002, K. D. Christensen and F. P. Jensen studied the bird migration over the coastal plains along the western shore of the Gulf of Suez and adjacent foothills of the Red Sea Mountains between the town of Suez and Port Safaga. The work provided information on bird migration in the Gulf of Suez area for future environmental impact 
assessment of wind farms. It was conducted in autumn 1998 (1 September - 6 November), spring and autumn 1999 (1 March - 10 May and 13 August - 12 September, respectively). 18 species (mostly raptors) and some nocturnal migrants (about 17 warblers and other species) were recorded (Christensen and Jensen 2002).

\section{Passerines' migration strategies across the Mediterranean and Sahara Desert}

Migration studies in the north Sahara, especially Egypt, attracted the scientists since the 1970s, when they started to study avifauna diversity and distribution with different monitoring methodologies including bird ringing. During such studies a lot of recoveries of birds ringed or recovered in Egypt were recorded.

Crossing the Mediterranean Sea and Sahara was very interesting question to answer. A lot of scientists tried to answer this question as Sahara extends from the Atlantic coast in the west to the Saudi Arabian peninsula in the east, leaving no way to fly around. The Sahara north to south covers about $2000 \mathrm{~km}$ of extremely inhospitable land with stony, rocky desert, mountain depression and very few oases. To cross this barrier birds would have to fly continuously for 30 to $40 \mathrm{~h}$. The first issue was: how can small birds cross such huge ecological barriers?

There are two general hypotheses: (1) non-stop flight, i.e. birds fly through Sahara to the Sahel zone without a stop; (2) intermittent migration strategy, i.e. migrants stop during the day and fly during the evening and night.

The studies that supported or argued against one of these two hypotheses are as following. Moreau (1961, 1972) proposed non-stop flight from the Mediterranean area in the north to the Sahel zone in the south during autumn migration and birds landing in the Sahara should be "fallouts". Several authors studying the physiology and behaviour of grounded birds before crossing the desert (Finlayson 1981, Moreau 1969, Moreau and Dolp 1970) and after crossing the south of Sahara (Ludlow 1966, Fry et al. 1970, Dowsett and Fry 1971, Fry 1971, Pearson 1971, Wood 1978) reported that some fatty, but mostly medium fat birds grounded in the Libyan and Western Desert in autumn. Biebach (1985) studied Sahara stopover in migratory flycatchers and proposed that fat and food affected the time program. The work was conducted in Bahariya Oasis of the Egyptian Western Desert. This author asked the question, whether the time of stopover and migration activities depend on fat reserve and food possibilities, and it was concluded that: (1) long-distance migrants have inflexible endogenous, genetically determined program; (2) food deprivation at the beginning or during the migration does not affect migratory activities unless fat reserve was completely depleted, birds with low fat reserve may stay 2-29 days.

The same author (Biebach 1988) studied ecophysiology of the resting Willow Warblers (Phylloscopus trochilus) crossing the Sahara and the question was, whether resting birds in the desert were stragglers or they had stopped over. The Willow Warbler is the most numerous passerine species that passes the Sahara in autumn. Individuals of this species can rest as follows: between sunrise and noon the birds arrive at a stopover site, where they quickly choose resting place and stay there without moving and then they continue migration at sunset. The results of the study sup- 
ported the intermittent strategy, where birds of this species fly three nights and rest two days in the desert in order to successfully cross the Sahara.

Biebach et al. (1986) studied the interaction of body mass, fat, foraging and stopover period in trans-Sahara migrating passerine birds. In this paper three species, i.e. the Willow Warbler, Lesser Whitethroat (Sylvia curruca) and Yellow Wagtail (Motacilla flava) were studied in oasis and desert stations. It was concluded that the majority of migrants resting in the oasis area were too low in fuel, however another question was: why did lean birds rest preferably in the oasis whereas fat birds - out in the desert? The decision where to land depends on the available fat reserves of the individuals. Birds with subnormal fat depots depend on refuelling during the day. They only make a landfall at a place which promises food, such as an oasis, but not in a few bushes at a desert stand. Fat birds land and rest throughout the day, whenever there is a place which meets their thermal regulation needs.

Biebach (1990) studied strategies of trans-Sahara migrants. Four possible strategies of desert crossing were suggested: (1) movement along vegetated areas in the north-south direction with flight at night and stopover during the day (following the Nile or Atlantic coast); (2) flight from the oasis to oasis at night and stopover during the day (along a row of oases and mountains stretching south-east from Morocco); (3) flight over the desert at night and with daytime stopover in the desert; (4) non-stop flight over the entire Sahara Desert.

It was also mentioned that the combination of these four strategies was possible and factors controlling the scheme of crossing were: the energy and water budget of migrants, the effect of wind and temperature conditions. This means that under good weather condition (tail wind at high altitudes) all species make a non-stop flight, whereas under bad weather condition (head winds at high altitudes) some species make the intermittent and others non-stop flight.

Biebach et al. (1991) studied the daily pattern of autumn bird migration in the northern Sahara, where the temporal pattern of migration by passerine birds during the night and their arrival during the day at the Egyptian coast and in the northern Sahara Desert was investigated. A correlation between the number of migrants observed during the night and the number of resting birds in the desert on the following day suggested that an unknown proportion of birds might have regularly used the intermittent migratory strategy that included stopover periods during day when crossing the desert, whereas others might have adapted the non-stop migratory strategy.

Biebach (1992) calculated flight ranges during autumn migration. The necessary assumptions about air speed, energy input during flight, and energy equivalent of body reserves were evaluated. According to these results: (1) the Willow Warbler and Garden Warbler (Sylvia borin) with medium body-mass had flight range not enough to cover about half of the distance between the Mediterranean and the Sahel zone, (2) the energy reserves of the Willow Warbler and Garden Warbler before crossing the desert were not sufficient to reach the Sahel zone in still air without foraging on the flyway, (3) the safety margin of energy resources depended on the reliability and strength of tailwinds. Moreover, the unfavourable wind conditions might be the reason for the interruption of flight during the day. Finally, the adopted strategy would probably depend not only on energy budget, but on the water budget as well. 
Biebach (1996) studied stopover of migrants flying across the Mediterranean Sea and the Sahara. It was concluded that: (1) all birds had to have sufficient accumulation of energy and water before crossing the barriers (there was no significant opportunity to refuel anywhere in the desert), (2) a possible exception was found along the western route, where refuelling was feasible in the Atlas Mountains, (3) birds on the ground along the Mediterranean coast from Libya to Egypt were in good condition with a good chance of successful crossing the barrier.

There was positive evidence for the intermittent migratory strategy without ruling out the possibility of non-stop migration strategy. Biebach et al. (2000) made radar study to investigate the strategies of passerine migration across the Mediterranean Sea and the Sahara Desert. Radar observations on the number and time of a day of small bird migration in the Sahara Desert were done. Study sites were on a transect along the north-south migratory direction. Three groups of birds migrating either during a day, evening or night in the northern part of the Western Desert in Egypt were identified. The conclusion was that the three groups were assigned to three different strategies of migration across the Mediterranean Sea and the Sahara: (1) the day group of birds performed a non-stop flight across the sea and at least the northern part of the desert, (2) the night group performed an intermittent migratory strategy with a stopover at the coast of Egypt to continue migration the next evening, (3) the evening group birds were intermittent migratory fliers, but they stopped over somewhere in the desert after a continuous flight across the sea and part of the desert. About $20 \%$ of all migrants were involved in non-stop migration and $80 \%$ in intermittent migration with stopover at the coast $(60 \%)$ and in the desert $(20 \%)$.

\section{Direction, timing and factors affecting passerines migration}

Bruderer (2001) conducted field observations by radar, infrared, and moonwatching, trying to modify current views of nocturnal bird migration in the Mediterranean. This study provided a general view of the horizontal distribution and directions of nocturnal migration in the Mediterranean. Observations at particular sites showed adjustments of directions to topography, at some sites changing with the progress of the night. It was concluded that migratory behaviour seemed to be more varied and flexible than earlier hypotheses had suggested.

Aliabadian et al. (2005) conducted a study to identify contact zone hotspots of passerine birds in the Palearctic region. They analysed the geographical distribution of the contact zones for parapatric species pairs of passerine birds of the Palearctic region, which were located mainly in south-western, northern and central-southern Asia, and in north-western Africa, with a hotspot in the Middle East.

Erni et al. (2005) studied the role of wind in passerine autumn migration between Europe and Africa and the results suggested that the south-western flyway depended on the selection of days, but especially altitudes, with favourable wind conditions and on refuelling opportunities in NW Africa. The SE flyway is privileged by the frequent favourable wind conditions for crossing the eastern Mediterranean Sea and the Egyptian Desert, where refuelling sites are almost absent. Both autumn migration routes would be unlikely without wind assistance. 
Newton (2006) investigated the impact of conditions experienced during migration on the population levels of birds and assumed that some populations of migratory birds might be limited not only by conditions in breeding or wintering areas but also by conditions encountered on migration. This could occur at stopover sites where competition for restricted food supplies can reduce subsequent survival or breeding success, or during the flights themselves, when adverse weather can occasionally kill large numbers of individuals. The study showed that rates of weight gain, departure weights and stopover durations often correlated with food supplies at stopover sites, sometimes influencing the subsequent survival and reproductive success of individuals, which can in turn affect subsequent breeding numbers. He also stated that migrants in flight occasionally suffered substantial mortality in storms, especially over water, sometimes involving many thousands of birds at a time. Other mass mortalities resulted from atypical 'winter-like' weather, occurring soon after the arrival of summer migrants in their breeding areas or just before their departure in autumn.

Schmaljohann et al. (2007) studied the daytime passerine migrants over the Sahara and their question was: were these diurnal migrants or prolonged flights of nocturnal migrants? The hypothesis was that while crossing the Sahara nocturnal migrants would continue their flight into the day. They investigated whether migration taking place in the Sahara during daytime comprised the normal diurnal migrant species or the nocturnal ones prolonging their flight into the day. It was concluded that nocturnal passerine migrants were responsible for most of the recorded daytime passage (swifts, swallows and soaring birds being excluded). Flight and landing behaviour varied with environmental conditions and nocturnal passerine migrants adjusted their flight schedules opportunistically, continuing into the day in particularly favourable winds.

Yohannes et al. (2009) studied passerine migration strategies and body mass variation along geographic sectors across East Africa, the Middle East and the Arabian Peninsula. Using the body mass estimates of 12 long-distance migrating Palearctic passerine species monitored at successive sites across the Eastern Africa flyway, they tested whether birds modulated their body mass according to specific seasonal demands across different geographic sectors. They compared body mass estimates across latitudinal distances and geographic sectors in Europe, the desert, north east Africa and East Africa. The results showed that, depending on the species and season considered, the average body mass increase or decrease was variable at and among different geographic sectors. By comparing the variation in body mass between different ecological sectors, they were able to show when and where migrants accumulated their migratory fuel reserves during migration.

Marchetti and Zehtindjiev (2009) studied the migratory orientation of Sedge Warblers (Acrocephalus schoenobaenus) in relation to feeding and exploratory behaviour. They performed the orientation tests with Emlen funnels, which showed much variation, partially due to birds' personalities. The studies were performed on autumn passage at Kalimok Biological Station, Bulgaria. They concluded that birds that fed on the first day of stopover oriented in the expected, southward direction, while noneating birds were scattered. 
Miholcsa et al. (2009) studied change of timing of autumn migration of transSahara migrants - Acrocephalus and Locustella species caught in Ócsa (Hungary) with standardized conditions between 1987-2004. They constructed the cumulative diagram of the migration for adults and juveniles for every year and established the dates of the 50 and $90 \%$ percentiles. They represented these data in the function of years and the average temperatures of August. Although the study period was short, they found some significant changes in the timing of migration and correlations with the temperature. The early migrating species advanced their autumn migration and the later-migrating species delayed it. They finally concluded that migration strategies of the species were very complex, so it is hard to give a uniform explanation for the changes.

Yohannes et al. (2009), investigated migration speeds among eleven species of long-distance migrating passerines across Europe, the desert and eastern Africa. Based on phenology, passage and median dates gathered from large number of study sites, they measured autumn and spring migration speeds of eleven long-distance migratory passerines in four different ecogeographic sectors: Europe, desert, northeastern and eastern Africa. Results demonstrated that, during the southward autumn migration, late-departing species, such as the Lesser Whitethroat, Garden Warbler, Spotted Flycatcher (Muscicapa striata), Whitethroat (Sylvia communis), and Willow Warbler covered their migration route with a slower average migration speed across Europe than did early migrating species. During spring migration, late-departing species - Marsh Warbler (Acrocephalus palustris), Garden Warbler, Spotted Flycatcher, Red-backed Shrike (Lanius collurio) across north-eastern Africa showed a higher speed than early migrating species. The results showed overall shorter migration duration estimates in spring than autumn. Sector-wise seasonal comparisons of duration indicated that migration journey in the African and desert sectors were covered in a relatively shorter time in spring than in autumn. Periods required to cover the distance between northern latitude breeding grounds and desert during both seasons were equivalent.

Bächler et al. (2010) conducted year-round tracking of small trans-Saharan migrants using light-level geolocators. They showed for the first time year round tracks of a near passerine trans-Saharan migrant, the European Hoopoe (Upupa epops epops). They found a low level of migratory connectivity between breeding and wintering areas and they also stated that tracking with light-level geolocators opened a new chapter in the research of Palearctic-African bird migration as this new tool revolutionized ability to discover migration routes, stopover sites and wintering grounds of small birds.

Pasinelli et al. (2011) studied the impact of density and environmental factors on population fluctuations in a migratory passerine. They analysed time series from six Central European populations of the migratory Red-backed Shrike by simultaneously assessing the strength of density dependence, process and sampling variance. In addition, they evaluated hypotheses predicting effects of factors presumed to operate on the breeding grounds, at stopover sites in eastern Africa during fall and spring migration and in the wintering grounds in southern Africa. The study highlighted the importance of jointly investigating density-dependent and density-independent pro- 
cesses to improve our understanding of factors influencing population fluctuations in space and time.

\section{Bird ringing in Egypt}

Ringing operations in Egypt commenced in 1937 and the vast majority of birds handled since then have been fitted with Giza Zoological Museum rings. The first relatively intensive program was conducted between 1937 and 1948 by ringers associated with Giza Zoological Museum and the Zoological Society of Egypt. Mackintosh (1941) reported the species composition and number of individuals handled up to 1940. The most common ringed birds during this period were ducks, dominated by the Pintail (Anas acuta) and the Pied Wagtail (Motacilla alba) - 8298 and 2232 indiv., respectively.

During the period from spring 1949 to 1954 a concentrated effort of bird ringing was conducted when British military personnel intermittently operated Heligoland trap at Fayid along the Great Bitter Lake. The ringing scheme and part of the information gathered at this site were reported by Brownlow $(1952,1960)$ and Simmons (1954b). The data from the last years of this project were lost.

Between 1966 and 1973 the fieldworkers of the Palaearctic Migratory Bird Survey ringed over 76000 birds mostly along the North Coast near Bahig. Information on the ringing program was published by Hubbard (1967), Hubbard and Horner (1969). Watson (1971) summarized the work conducted until the autumn of 1970. Over 47000 birds of 75 species were ringed according to the Giza Zoological Museum ringing files.

Since Watson's report (Watson 1971) a considerable number of foreign ringed birds were recovered in Egypt. A large percentage of this information can be found in Giza Zoological Museum ringing files and Euring Data Bank. Most of them comes from reports by various Eurasian and African national ringing centres. The vast majority of this information is summarized along with previously published records, in the species account. There were made serious attempts to double check many of these recoveries through correspondence with the ringing centres and/or by checking the literature. Information is outstanding for several hundred foreign birds recovered in Egypt and reported to the original ringing centre (Goodman et al. 1989). About 100000 birds were ringed in Egypt till the 1980s. By May 1988 a total of 1337 recoveries of at least 90 species were collected. Out of these, 237 were birds ringed in Egypt and recovered within the country or abroad and 1064 were birds ringed abroad and recovered in Egypt. Of the recoveries, $76 \%$ were of 10 species and much of this information was mapped under respective species accounts under chapter 6 of the book by Goodman et al. (1989). The 10 species included the White Stork (Ciconia ciconia) 299 indiv., the Slender-billed Gull (Larus genei) - 212 indiv., the Quail (Coturnix coturnix) - 98 indiv., the Pintail (Anas acuta) - 57 indiv., the Caspian Tern (Hydroprogne caspia) - 76 indiv., the Pied Wagtail - 69 indiv., the Lesser Black-backed Gull (Larus fuscus) - 52 indiv., the Red-backed Shrike - 60 indiv., the Lesser Whitethroat - 51 indiv. and the Willow Warbler - 48 indiv.

Contemporarily in Egypt, ringing activities restarted in 2001 in collaboration with the SEEN (SE European Bird Migration Network - for details see www.seen-net.eu) 
in Wadi El Rayan to study the possibility for establishing scientific bird ringing station following the international standards for such scientific stations and evaluate the possibility for extending this work to other protected areas. During 22 seasons starting from 2001, 7 sites have been investigated for passerine migration through conducting successful bird ringing schemes at field stations working efficiently during spring and autumn migration seasons. These sites are: Mansala protected area, $\mathrm{Bu}-$ rullus protected area, Wadi El Rayan protected area, Hurghada, Sharm El Sheikh (Ras Mohamed national park), Saluga and Ghazal protected area (Aswan), Wadi El Gemal protected area. Ringing procedures were according to the standard SEEN bird ringing methodology, including bird species identification, measurements and orientation tests for determining the preferred migration direction of passerines at each station (Busse 2000). Altogether, till 2008, more than 31000 individuals of 117 species were ringed (and another 2000 in 2010) and two reports were published (Hasseb et al. 2004, Zaniewicz and Chruściel 2011).

\section{CONCLUSIONS}

The bird migration studies as well as the collection of avifaunistic data were performed in Egypt quite a long time in the past century and contemporary. However, most of interest was directed to studies of well visible diurnal migrants, as storks and raptors as well as waterbirds, which are of a great concern of bird protection organizations. Nocturnal migrants, being the majority of bird individuals migrating over Egypt were studied much less. This caused that the knowledge of their problems is much lower. Most of field studies performed were a short-term expeditions covering short parts of the migration time, which lasts here around three months per season. Observations were not repeated season by season and locations were studied in different years, thus repeatability of migration in a defined place is not known. All these weaknesses make the general picture of nocturnal migration very incomplete. Despite the fact that during last years some very important bird resting locations were found there are no plans to organize permanent ornithological bird migration stations. As passerines are an important part of the Egyptian biodiversity and a huge share of the bird biomass, the permanent studies are highly advisable.

\section{REFERENCES}

Al Hussaini A.H. 1938a. Some birds observed in Ghardaqa (Hurghada) Red Sea coast. Ibis 80, 3: 541-544. DOI: 10.1111/j.1474-919X.1938.tb00590.x

Al Hussaini A.H. 1938b The avifauna of the Bahariya Oasis in winter. Ibis 80, 3: 544-547. DOI: 10.1111/j.1474-919X.1938.tb00591.x

Al Hussaini A.H. 1938-1939. An ornithological trip to Siwa Oasis. Bull. de l'Inst. D’Egypte 21: 145-152.

Al Hussaini A.H. 1939. Further notes on the birds of Ghardaqa (Hurghada), Red Sea. Ibis 81, 2: 343-347. DOI: 10.1111/j.1474-919X.1939.tb03980.x

Al Hussaini A.H. 1954. Birds of Egypt. Anglo-Egyptian Library, Cairo. (In Arabic). 
Aliabadian M., Roselaar C.S., Nijman V, Sluys R., Vences M. 2005. Identifying contact zone hotspots of passerine birds in the Palaearctic region. Biol. Lett. 1: 21-23. DOI: $10.1098 / \mathrm{rsbl} .2004 .0258$

Bächler E., Hahn S., Schaub M., Arlettaz R., Jenni L., Fox J.W., Afanasyev V., Liechti F. 2010. Year-Round Tracking of Small Trans-Saharan Migrants Using Light-Level Geolocators. PLoS ONE 5, 3: e9566. DOI: 10.1371/journal.pone.0009566

Baha El Din M., Baha El Din S., Shobrak M. 2003. Status of Breeding Seabirds in the Egyptian Red Sea. Report to PERSGA, PERSGA, Jeddah: 30 pp.

Baha El Din S.M. 1999. Directory of Important Bird Areas in Egypt. Palm Press, Cairo.

Baha El Din S., Salama W. 1984. Waterbird migration study at Zaranik, Sinai. 2-24 September 1982. Courser 1: 28-43.

Biebach H. 1985. Sahara stopover in migratory flycatchers: fat and food affect the time program. Experientia 41, 5: 695-697. DOI: 10.1007/BF02007727

Biebach H. 1988. Ecophysiology of resting Willow Warbler (phylloscopus trochilus) crossing the Sahara. Proc. XIX ${ }^{\text {th }}$ Int. Ornithol. Congr.: 2162-2168.

Biebach H. 1990. Strategies of trans-Sahara migrants. In: Gwinner E. (Ed.). Bird migration: physiology and ecophysiology. Springer Verlag, Berlin: 352-367.

Biebach H. 1992. Flight range estimates for small trans-Sahara migrants. Ibis 134: 47-54. DOI: 10.1111/j.1474-919X.1992.tb04733.x

Biebach H. 1996. Energetics of winter and migratory fattening. In: Carey C. (Ed.). Avian energetics and nutritional ecology. Chapman \& Hall, New York: 280-323.

Biebach H., Friedrich W., Heine G. 1986. Interaction of body mass, fat, foraging and stopover period in trans-Sahara migrating passerine birds. Oecologia 69: 370-379.

Biebach H., Biebach I., Friedrich W., Heine G., Partecke J., Schmidl D. 2000. Strategies of passerine migration across the Mediterranean Sea and the Sahara Desert: a radar study. Ibis 142: 623-634. DOI: 10.1111/j.1474-919X.2000.tb04462.x

Biebach H., Friedrich W., Heine G., Jenni L., Jenni-Eiermann S., Schmidl D. 1991. The daily pattern of autumn bird migration in the northern Sahara. Ibis 133: 414-422. DOI: 10.1111/j.1474-919X.1991.tb04590.x

BirdLife International. 2005. www.birdlife.org/worldwide/index.html

Brownlow H.G. 1952. A ringing station in Egypt. Ibis 94: 128-132. DOI: 10.1111/j.1474-919X.1952.tb01793.x B

Brownlow H.G. 1960. Migrational fidelity in Egypt. Ibis 102: 126. DOI: 10.1111/j.1474-919X.1960.tb05099.x

Bruderer B. 2001. Recent studies modifying current views of nocturnal bird migration in the Mediterranean. Avian Ecol. Behav. 7: 11-25.

Busse P. 2000. Bird Station Manual. SE European Bird Migration Network, Univ. of Gdańsk, Gdańsk.

Christensen K.D., Jensen F.P. 2002. Atlas of Bird Migration at the Gulf of Suez, Egypt. Egypt Ministry of Foreign Affairs, Danida, Ornis Consult Ltd., Copenhagen.

David A.R. 1997. The Pyramid Builders of Ancient Egypt: A Modern Investigation of Pharaoh's Workforce. Routledge: p. 14.

Dowsett R.J., Fry C.H. 1971. Weight losses of trans-Saharan migrants. Ibis 113: 531-533.

El Negumi A. 1949. List of desert animals seen or collected during the periods shown. Bull. Zool. Soc. Egypt 8: 20-1.

El Negumi A., Zain El Din H.F., El Moiery M.A., Fayed M.K. 1950. Birds of Egypt. Daar el Fikr el Arabi, Cairo. (In Arabic).

Encyclopaedia Britannica. 2011. http://www.britannica.com/EBchecked/topic/180382/Egypt/ 43453/Climate

Erni B., Liechti F., Bruderer B. 2005. The role of wind in passerine autumn migration between Europe and Africa. Behav. Ecol. 16, 4: 732-740. DOI: 10.1093/beheco/ari046 
Finlayson J.C. 1981. Seasonal distribution, weights and fat of passerine migrants at Gibraltar. Ibis 123: 88-95. DOI: 10.1111/j.1474-919X.1981.tb00176.x

Fishpool L.D.C., Evans M.I. (Eds). 2001. Important Bird Areas in Africa and associated islands: Priority sites for conservation. BirdLife Conserv. Ser. 11.

Frazier J.G., Salas S.S., Saleh M.A. 1984. Ornithological observations along the Egyptian Red Sea coast, spring 1982: with notes on migratory and breeding species. Courser 1: 17-27.

Fry C.H. 1971. Migration, moult and weights of birds in northern Guinea savanna in Nigeria and Ghana. Ostrich, Suppl. 8: 239-260.

Fry C.H., Ash J.S., Ferguson-Lees I.J. 1970. Spring weights of some Palaearctic migrants at Lake Chad. Ibis 112: 58-82. DOI: 10.1111/j.1474-919X.1970.tb00076.x

Goodman S.M., Ames P.L. 1983. A contribution to the ornithology of the Siwa Oasis and Qattara Depression, Egypt. Sandgrouse 5: 82-96.

Goodman S.M., Meininger P.L. (Eds)., Baha El Din S.M., Hobbs J.J., Mullié W.C. 1989. The birds of Egypt. Oxford Univ. Press, Oxford.

Goodman S.M., Meininger P.L., Mullié W.C. 1986. The birds of the Egyptian Western Desert. Misc. Publ. Univ. Michigan Mus. Zool. 172: 1-91.

Goodman S.M., Storer R.W. 1987. The seabirds of the Egyptian Red Sea and adjacent water, with notes on selected Ciconiiformes. Gerfaut 77: 201-204.

Goodwin D. 1949. Notes on the migration of birds of prey over Suez. Ibis 91: 59-63. DOI: 10.1111/j.1474-919X.1949.tb02236.x

Goodwin E.G.M. 1947a. A Middle East migration. New facts about a little-known movement of birds of prey. Field 189: 182.

Goodwin E.G.M. 1947b. Radar and the speed of birds. Illustrated London News, Nov. 15: 552.

Greaves R.H. 1945. Notes on the future study of birds' migration in Egypt. Bull. Zool. Soc. Egypt 7: $58-63$.

Grieve A., Millington L.B. 1999. The Breeding Birds of the Northern Red Sea Islands, Egypt: A report on a survey of the birds nesting on islands at the mouth of the Gulf of Suez, Red Sea, Egypt in 1998. Bedfordshire.

Hasseb M., Ibrahim W., Asran H., Deyab A., Gomaa M., Hassan S., Nowakowski J.K., Busse P. 2004. Saluga and Ghazal Ringing Station - a new ringing station in Egypt. Ring 26, 2: 93-99.

Hoath R., Russell D., Khalil R., Khalil D. 1997. The birds of the islands at the mouth of the Gulf of Suez, Egyptian Red Sea. Sandgrouse 19, 2: 22-29.

Hoogstraal H., Kaiser M.N. 1961. Ticks from European-Asiatic Birds Migrating through Egypt into Africa. Science 133, 3448: 277-278. DOI: 10.1126/science.133.3448.277

Hoogstraal H., Kaiser M.N., Traylor M.A., Gaber S., Guindy E. 1961. Ticks (Ixodoidea) on birds migrating from Africa to Europe and Asia. Bull. World Health Organ. 24, 2: 197-212.

Hoogstraal H., Kaiser M.N., Traylor M.A., Guindy E., Gaber S. 1963. Ticks (Ixodidae) on birds migrating from Europe and Asia to Africa, 1959-61. Bull. World Health Organ. 28, 2: 235-262.

Hoogstraal H., Traylor M.A., Gaber S., Malakatis G., Guindy E., Helmy I. 1964. Ticks (Ixodidae) on migrating birds in Egypt, spring and fall 1962. Bull. World Health Organ. 30, 3: 355-367.

Hopkins N.S., Westergaard K. 1998. Directions of Change in Rural Egypt. American University in Cairo Press, Cairo.

Horner K.O. 1977. A statistical analysis of spring bird migration at Bahij, Arab Republic of Egypt. Ph.D. thesis, Virginia Polytechnic Institute and State University.

Horváth L. 1958. A new race of the Desert Lark from Egypt. Bull. Brit. Ornithol. Club 78: 124-125.

Horváth L. 1959. The results of the zoological collecting trip to Egypt in 1957, of the Natural History Museum, Budapest - 7. The ornithological results. Ann. Hist.-Nat. Mus. Natl. Hung. 51: 451-481.

Hubbard J.P. 1967. Birds ringed in Egypt 1966/67. Ring 52, 3: 62-63. 
Hubbard J.P., Horner K.O. 1969. Recent progress of the Egyptian ringing program. Ring 59: 216-217.

IUCN 2000. IUCN, Red List of Threatened Animals. IUCN, Gland and Cambridge.

Jennings M.C., Heathcote P.C., Parr D., Baha El Din S.M. 1985. Ornithological Survey of the Ras Dib area and the islands at the mouth of the Gulf of Suez, Egypt. Oil Pollution Research Unit, Pembroke.

Koenig A. 1907a. Die Geier Aegyptens. J. Ornithol. 55, 1: 59-134. DOI: 10.1007/BF02098853

Koenig A. 1907b. Die Falconiden Aegyptens. J. Ornithol. 55, 3: 391-469. DOI: 10.1007/BF02089322

Koenig A. 1907c. Die Falconiden Aegyptens. J. Ornithol. 55, 4: 549-582. DOI: 10.1007/BF02092049

Koenig A. 1917. Die Eulen ägyptens. J. Ornithol. 65, 2: 129-160. DOI: 10.1007/BF02327951

Koenig A. 1919. Die Sperrschnäbler (Fissirostres) Aegyptens. J. Ornithol. 67: 431-432. DOI: 10.1007/BF02539449

Koenig A. 1920a. Die Sitzfüßler (Insessores) Aegyptens. J. Ornithol. 68, Suppl. 1: 3-76. DOI: 10.1007/BF02538829

Koenig A. 1920b. Die Klettervögel (Scansores) Aegyptens. J. Ornithol. 68, Suppl. 1: 79-82. DOI: 10.1007/BF02538830

Koenig A. 1920c. Die Rabenartigen Vögel (Coraces) Aegyptens. J. Ornithol. 68, Suppl. 1: 85-148. DOI: $10.1007 / \mathrm{BF} 02538831$

Koenig A. 1921. Die Fänger (Captores) Aegyptens. J. Ornithol. 69, 3: 426-456. DOI: 10.1007/BF02537530

Koenig A. 1924. Die Sänger (Cantores) Aegyptens. J. Ornithol. 72, Suppl. 1: 3-247. DOI: 10.1007/BF02075965

Koenig A. 1926a. Die Kegelschnäbler (Conirostres) Aegyptens. J. Ornithol. 74, 4: 7-44. DOI: 10.1007/BF02002401

Koenig A. 1926b. Die Tauben (Columbae) Aegyptens J. Ornithol. 74, 4: 45-70. DOI: 10.1007/BF02002402

Koenig A. 1926c. Die Scharr- oder Hühnervögel (Rasores) Aegyptens. J. Ornithol. 74, 4: 71-108. DOI: $10.1007 / \mathrm{BF} 02002403$

Koenig A. 1928. Fortsetzung und Schlufs der Watvögel (Grallatores) Aegyptens. J. Ornithol. 76, 1: 3-306. DOI: 10.1007/BF02088959

Koenig A. 1932a. Die Schwimmvögel (Natatores) Aegyptens. J. Ornithol. 80, Suppl. 1: 3-192. DOI: 10.1007/BF01967607

Koenig A. 1932b. Die Ruderfüßer (Steganopodes) Aegyptens J. Ornithol. 80, Suppl. 1: 195-223. DOI: 10.1007/BF01967608

Koenig A. 1932c. Die Flügeltaucher (Urinatores) Aegyptens. J. Ornithol. 80, Suppl. 1: 226-237. DOI: $10.1007 / \mathrm{BF} 01967609$

Lavee D., Safriel U. 1974. Utilization of an oasis by desert-crossing migrants. Isr. J. Zool. 23: 219.

Ludlow A.R. 1966. Body weight changes and moult of some Palaearctic migrants in southern Uganda. Ibis 108: 129-132.

Mackintosh D.R. 1941. Bird ringing recoveries. Bull. Zool. Soc. Egypt 3: 7-29.

Marchetti C., Zehtindjiev P. 2009. Migratory orientation of sedge warblers (Acrocephalus schoenobaenus) in relation to eating and exploratory behaviour. Behav. Process. 82, 3: 293-300. DOI: 10.1016/j.beproc.2009.07.008

Meininger P.L., Atta G.A.M. (Eds). 1994. Ornithological studies in Egyptian Wetlands 1989/90. WIWO report 40, FORE-report 94.01, Zeist, the Netherlands.

Meininger P.L., Mullié W.C. 1982. Egyptian wetlands as threatened wintering areas for waterbirds. Sandgrouse 3: 62-77.

Meininger P.L., Sørensen U.G., Atta G.A.M. 1986. Breeding birds of the lakes in the Nile delta, Egypt. Sandgrouse 7: 1-20. 
Miholcsa T., Tóth A., Csörgő T. 2009. Change of timing of autumn migration in Acrocephalus and Locustella genus. Acta Zool. Acad. Sci. H. 55, 2: 175-185.

Misonne X. 1974. Les oiseaux du Kufra et du Jebel Uweinat. Gerfaut 64: 41-73.

Moreau R.E. 1961. Problems of Mediterranean-Saharan migration. Ibis 103: 373-427. DOI: 10.1111/j.1474-919X.1961.tb02454.x

Moreau R.E. 1969. Comparative weights of some trans-Saharan migrants at intermediate points. Ibis 111: 62-624. DOI: 10.1111/j.1474-919X.1969.tb02580.x

Moreau R.E. 1972. The Palaearctic-African Bird Migration Systems. Acad. Press, London - New York.

Moreau R.E., Dolp R.M. 1970. Fat, water, weights and wing-lengths of autumn migrants in transit on the north-west coast of Egypt. Ibis 112: 209-228. DOI: 10.1111/j.1474-919X.1970.tb00094.x

Moreau R.E., Moreau W.M. 1937. Biological and other Notes on some East African Birds. Ibis 79: 152-174. DOI: 10.1111/j.1474-919X.1937.tb02167.x

Newton I. 2006. Can conditions experienced during migration limit the population levels of birds? J. Ornithol. 147, 2: 146-166. DOI: 10.1007/s10336-006-0058-4

Nicoll M.J., Meinertzhagen R. 1930. Nicoll's Birds of Egypt. vol. I and II. Hugh Rees, London.

Pasinelli G., Schaub M., Häfliger G., Frey M., Jakober H., Müller M., Stauber W., Tryjanowski P., Zollinger J.-L., Jenni L. 2011. Impact of density and environmental factors on population fluctuations in a migratory passerine. J. Anim. Ecol. 80, 1: 225-234. DOI: 10.1111/j.1365-2656.2010.01754.x.

Pearson D.J. 1971. Weight of some Palaearctic migrants in southern Uganda. Ibis 113: 173-185. DOI: $10.1111 / \mathrm{j} .1474-919 X .1971 . t b 05142 . x$

Petersen I., Sørensen U.G. 1980. Ornithological observations from the lagoon, north Sinai, Egypt, October 1979. Private printing, Humble/Copenhagen.

Petersen I., Sørensen, U.G. 1981a. Migrational studies from the eastern part of the lagoon 'Sabkhet el Bardawil' on the north coast of the Sinai Peninsula. 7-30 September 1980. Private printing, Copenhagen.

Petersen I., Sørensen U.G. 1981b. Third Danish ornithological expedition to Egypt, autumn 1981. Preliminary report. Private printing, Copenhagen.

Reed Ch. 1966. The Yale University Prehistoric Expedition to Nubia, 1962-1965. Discovery, Yale Peabody Mus. 1, 2: 16-23.

Rosenzweig M. 1988. A 1988 status report of the Red Sea islands off the coast of Hurghada. Courser 2: 39-43.

Schmaljohann H., Liechti F., Bruderer B. 2007. Daytime passerine migrants over the Sahara are these diurnal migrants or prolonged flights of nocturnal migrants? Ostrich 2007, 78, 2 : 357-362.

Short L.L., Horne J.F.M. 1982. Bird observations along the Egyptian Nile. Sandgrouse 3: 43-61.

Simmons K.E.L. 1951. Raptor migration in the Suez area: Autumn 1949 - Spring 1950. Ibis 93: 402-406. DOI: 10.1111/j.1474-919X.1951.tb05442.x

Simmons K.E.L. 1952. Some observations on the Olivaceous Warbler Hippolais pallida in Egypt. Ibis 94: 203-209. DOI: 10.1111/j.1474-919X.1952.tb01813.x

Simmons K.E.L. 1954a. The behaviour and general biology of the Graceful Warbler Prinia gracilis. Ibis 96: 262-292. DOI: 10.1111/j.1474-919X.1954.tb04128.x

Simmons K.E.L. 1954b. Field-notes on the behaviour of some Passerines migrating through Egypt. Ardea 42: 140-151.

Varty N., Baha El Din S.M., Salama W. 1990. Assessment of the importance of Lake Bardawil for birds and the likely impact of the North Sinai agricultural development project on the region's bird populations and habitats. ICBP, Cambridge: $12 \mathrm{pp}$.

Watson G.E. 1971. A serological and ectoparasite survey of migratory birds in northeast Africa: final report. Smithsonian Inst., Natl Mus. Nat. Hist., Washington DC.

Wikipedia 2011. http://en.wikipedia.org/wiki/Geography_of_Egypt 
Wood B. 1978. Weights of Yellow Wagtails wintering in Nigeria. Ring. \& Migr. 2, 1: 20-26. DOI: 10.1080/03078698.1978.9673730

Yohannes E., Biebach H., Nikolaus G., Pearson D.J. 2009. Migration speeds among eleven species of long-distance migrating passerines across Europe, the desert and eastern Africa. J. Avian Biol. 40, 2: 126-134. DOI: 10.1111/j.1600-048X.2008.04403.x

Yohannes E., Biebach H., Nikolaus G., Pearson D.J. 2009. Passerine migration strategies and body mass variation along geographic sectors across East Africa, the Middle East and the Arabian Peninsula. J. Ornithol. 150: 369-381. DOI 10.1007/s10336-008-0357-z

Zaniewicz G., Chruściel J. 2011. Burullus ringing station (N Egypt) - ringing results and seasonal bird migration dynamics in 2005-2007. Ring 33, 1-2: 77-87. 